\title{
Effects of phosphorus supply on phagotrophy by the mixotrophic alga Uroglena americana (Chrysophyceae)
}

\author{
Jotaro Urabe*, Tek Bahadur Gurung, Takehito Yoshida \\ Center for Ecological Research, Kyoto University, Kamitanakami Hirano-cho 509-3, Otsu 520-2113, Japan
}

\begin{abstract}
The mixotrophic alga Uroglena americana forms a dense 'bloom. in Lake Biwa, Japan, in spring when dissolved inorganic phosphorus is in short supply relative to the requirements for algal growth. To assess the possibility that this alga uses bacteria as a substitutable P source via phagotrophy, feeding experiments were conducted using bacteria-sized fluorescent microspheres as tracer particles. The experiments revealed that the ingestion rate of $U$. americana on the food particles (bacteria + microspheres) is significantly affected by the concentrations of phosphate as well as food particles in the lake water. The response of ingestion rate to phosphate concentration indicated that $P$ levels $\geq 0.4 \mu \mathrm{M} \mathrm{P}$ were enough to reduce bacterivory by this alga. However, phosphate concentration had no effect on ingestion rate in heterotrophic nanoflagellates. These results suggest that $U$. americana can utilize bacteria as a substitutable $P$ source. Such an ability favors the development and maintenance of dense blooms by this alga under P-limited conditions.
\end{abstract}

KEV WORDS: Mixotrophs $\cdot$ Phagotrophy $\cdot$ Phosphorus $\cdot$ Lake Biwa $\cdot$ Uroglena $\cdot$ Red-tide

\section{INTRODUCTION}

Ingestion of bacteria is known in several algal taxa, including Chrysophyceae (Sanders \& Porter 1988, Raven 1997). These algae are defined as mixotrophs because of dual modes of nutrition, phototrophy and phagotrophy. Gain of energy or carbon (Bird \& Kalff 1986, Caron et al. 1990, Rothhaupt 1996), acquisition of major nutrients (nitrogen and phosphorus: Caron et al. 1993, Nygaard \& Tobiesen 1993, Rothhaupt 1996), and acquisition of organic biochemicals (vitamins and phospholipids: Aaronson \& Baker 1959, Kimura \& Ishida 1989, Caron et al. 1993) have been proposed to be the likely function of phagotrophy in mixotrophic algae. Variation among these studies suggests that the nutritional basis for bacterial ingestion by mixotrophic algae is species-specific or even variable within a species

Much evidence has accumulated over the last decade that mixotrophic algae are common constituents

•E-mail: urabe@ecology.kyoto-u.ac.jp of plankton communities (Bird \& Kalff 1986, Sandgren 1988, Sanders et al. 1989, Bennett et al. 1990). In marine coastal waters, mixotrophic algae sometimes develop dense blooms, including red-tides (e.g. Nygaard \& Tobiesen 1993). Similar blooms can be seen in Lake Biwa, the largest lake in Japan, where Uroglena americana has formed variably dense blooms in spring since 1977 that some researchers have called 'freshwater red-tides' (Ishida et al. 1982, Yoshida et al. 1983). Kimura \& Ishida (1986a) concluded that phagotrophy is an obligate mode of nutrition in $U$. americana because they cannot grow without bacteria. Furthermore, Kimura \& Ishida (1989) used culture experiments to show that phospholipids are the nutritional factor essential to the growth of this chrysophycean species. Additional studies by Kimura \& Ishida (1986b) showed that the phospholipids supporting growth of this alga are ubiquitous in natural bacteria. These findings suggest that obtaining key phospholipids is a prime motivation for bacterivory by $U$. americana.

In Lake Biwa, phosphorus is the most deficient nutrient for algal growth (Tezuka 1985). Field studies by 
Ishida et al. (1982) showed that algal growth was most limited by P just before Uroglena americana developed its dense spring bloom. Thus, an additional benefit from bacterivory by $U$. americana that contributes to its ability to achieve high densities in Lake Biwa might be the acquisition of a limiting nutrient, especially $P$. Algae are generally inferior to bacteria in competition for dissolved $\mathrm{P}$ because of their low affinity for phosphate at low concentrations (Currie \& Kalff 1984, Rothhaupt \& Güde 1992). However, if they assimilate P in bacteria, mixotrophic species should have a dual advantage in developing and sustaining their bloom in a P-limited environment, because they can not only depress a superior competitor (bacteria) for $\mathrm{P}$ but also obtain P through phagotrophy (Nygaard \& Tobiesen 1993, Thingstad et al. 1996).

Although some bacterial phospholipids appear essential in the growth of Uroglena americana (Kimura \& Ishida 1989), there is no a priori reason that this species ingests bacteria solely to acquire phospholipids. P uptake itself is also essential for algae to synthesize key biomolecules such as RNA, a major component of cellular P (Elser et al. 1996). Thus, when P is deficient in ambient water, $U$. americana may enjoy an extra advantage by obtaining $\mathrm{P}$ through phagotrophy. If this is true, we would predict that the feeding rate of $U$. americana on bacteria should increase when biologically available $\mathrm{P}$ is in short supply in ambient water. In the work presented here, we examined this possibility by measuring the feeding rate of $U$. americana on bacteria-sized fluorescent microspheres under different $\mathrm{P}$ concentrations.

\section{MATERIALS AND METHODS}

Three experiments were performed in spring 1997 and 1998 when Uroglena americana were abundant in Lake Biwa. During that time, the concentration of soluble reactive phosphorus (SRP) was less than $0.07 \mu \mathrm{M}$, and algal growth was limited by phosphorus (Urabe et al. unpubl.). In all experiments, live samples were collected with a modified Van Dorn Sampler from $2.5 \mathrm{~m}$ depth in the offshore pelagic zone, $4 \mathrm{~km}$ off the west coast of Lake Biwa's north basin. Lake water was transported to the laboratory within $2 \mathrm{~h}$ after sampling and gently filtered through a $100 \mu \mathrm{m}$ mesh to remove large zooplankton. Since the colony size of $U$. americana was relatively small when experiments were made, most of them passed through this mesh size. Microscopic inspection showed that $U$. americana remained in colonies and swam actively after the filtration. Experiments were done at the same water temperature as that where samples were collected
Expt 1 was done in May 1997 to examine the effects of nutrient enrichment on Uroglena americana. To initiate the experiment, $1 \mathrm{I}$ polycarbonate bottles were filled with $1 \mathrm{l}$ of filtered lake water containing $U$. americana. Two out of the 4 bottles received $2.5 \mu \mathrm{M}$ $\mathrm{K}_{2} \mathrm{HPO}_{4}, 18 \mu \mathrm{M} \mathrm{NH}{ }_{4} \mathrm{Cl}$ and $8.3 \mu \mathrm{M}$ glucose $(+\mathrm{P}$ treatment); the 2 other bottles received no nutrients and served as controls ( $-\mathrm{P}$ treatment). From the filtered lake water, aliquots were sampled to determine the initial densities of bacteria, $U$. americana and heterotrophic nanoflagellates (hereafter, HNF; species were not identified). Bottles were placed in a constant temperature room $\left(20^{\circ} \mathrm{C}\right)$ with 'cool-white' fluorescent lighting $\left(250 \mu \mathrm{E} \mathrm{m}^{-2} \mathrm{~s}^{-1}\right)$ under an $18 \mathrm{~h}: 6 \mathrm{~h}$ light:dark cycle. After $48 \mathrm{~h}$, aliquots were fixed with glutaraldehyde ( $2 \%$ final conc.) to estimate the final densities of bacteria, $U$. americana and HNF.

Expt 2 was done in late April 1998. In this experiment, we created a gradient of phosphate concentrations to examine the relationship between the bacterial feeding rate of flagellates and phosphate concentration in the water. The feeding rate was measured using $0.5 \mu \mathrm{m}$ diameter fluorescent microspheres (Fluoresbrite YG Microspheres, Polysciences, Inc.) as tracer food, because the size of these microspheres was comparable to that of bacteria in Lake Biwa (Nagata 1986). To initiate the experiment, $120 \mathrm{ml}$ of the filtered lake water was poured into $150 \mathrm{ml}$ polycarbonate bottles. Then, $6 \mathrm{P}$ treatments were done in duplicate or triplicate by adding either $0,0.1,0.25,0.5,1.0$ or $2.5 \mu \mathrm{M}$ $\mathrm{KH}_{2} \mathrm{PO}_{4}$ to the bottles. No nutrient other than $\mathrm{P}$ was added. In the 0 and $2.5 \mu \mathrm{M}$ P treatments, 2 additional bottles were prepared for the time $=0$ sample (see below). In addition to these treatments, we applied a $\mathrm{K}$ treatment in which $2.5 \mu \mathrm{M} \mathrm{KCl}$ was added to the bottles to check for the possible effects of potassium on the feeding rate of Uroglena americana. This $\mathrm{K}$ treatment was done in triplicate. All bottles were placed in a dark incubator $\left(16^{\circ} \mathrm{C}\right)$. After $1 \mathrm{~h}$ acclimatization, microspheres were added to each bottle to a final concentration of $4.02 \times 10^{5} \mathrm{ml}^{-1}$. Soon after, $50 \mathrm{ml}$ was collected from the bottles prepared for the time $=0$ sample and fixed with ice-cold glutaraldehyde ( $2 \%$ final conc.) as in Sanders et al. (1989). From the other bottles, two $50 \mathrm{ml}$ samples were collected after $15 \mathrm{~min}$ feeding for final samples. One of these samples was immediately fixed with ice-cold glutaraldehyde as above and used to determine the density of bacteria and clearance rate of flagellates for the microspheres. The second sample was not fixed and was used to measure the phosphate concentration at the end of incubation.

In May 1998, Expt 3 was performed in a $2 \times 2$ factorial design to examine if the effects of phosphate on ingestion rate changed according to the density of food particles. To manipulate bacterial density, $<100 \mu \mathrm{m}$ 
lake filtrate $(60 \mathrm{ml})$ was diluted with the same volume of lake water passed through $0.2 \mu \mathrm{m}$ Nuclepore filters, and poured into ten $150 \mathrm{ml}$ polycarbonate bottles. These bottles served as the low bacteria treatment (LB). The other 10 bottles received $120 \mathrm{ml}$ of $<100 \mu \mathrm{m}$ lake water alone and were used for the high bacteria treatment ( $\mathrm{HB}$ ). To 5 bottles of each bacteria treatment,

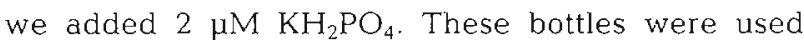
as phosphate treatment $(+\mathrm{P})$. The remaining bottles served as controls (-P). After $1 \mathrm{~h}$ acclimatization in a dark incubator $\left(18^{\circ} \mathrm{C}\right)$, we added fluorescent microspheres to the bottles to give a final concentration of $3.3 \times 10^{5} \mathrm{ml}^{-1}$ in HB treatments and $8.5 \times 10^{5} \mathrm{ml}^{-1}$ in LB treatments. Soon after, $50 \mathrm{ml}$ was collected from 2 bottles in each treatment for the time $=0$ samples. From the other bottles, samples were collected after $15 \mathrm{~min}$ feeding. These samples were treated as in Expt 2.

Bacteria were counted using the acridine orange direct count method (Hobbie et al. 1977). A 0.5 to $3.0 \mathrm{ml}$ aliquot of the sample was filtered onto $0.2 \mu \mathrm{m}$ pore-size black Nuclepore filters, and then bacteria were enumerated under an Olympus epifluorescence microscope $(1250 \times)$ equipped with a standard B-excitation system (100 W mercury lamp, BP 420-480 excitation filter) after staining with $0.005 \%$ acridine orange for 2 min. For each sample, at least 300 bacterial cells were counted. Phosphate concentration in experimental water was determined as SRP by the ascorbatereduced molybdenum blue method.

Microscope specimens for Uroglena americana and HNF were made with fluorescein isothiocyanate (Sherr \& Sherr 1983). 20 to $30 \mathrm{ml}$ of the sample was filtered onto $0.8 \mu \mathrm{m}$ pore-size black Nuclepore filters. Then, fluorescein isothiocyanate $(0.004 \%$, dissolved in sodium phosphate buffer of $\mathrm{pH}$ 7.2) was added, and the sample was stained for $30 \mathrm{~s}$. Flagellates were also observed under the epifluorescence microscope with the standard B-excitation system. Since colonies of $U$. americana were easily broken up to single cells by glutaraldehyde fixation, their cells were evenly distributed on the Nuclepore filters. We judged green-fluorescing flagellated cells to be HNF (Nagata 1988). For enumeration, an $80 \times 80 \mu \mathrm{m}$ eye-piece grid was used. Since 92 to $95 \%$ of $0.5 \mu \mathrm{m}$ microspheres passed through the $0.8 \mu \mathrm{m}$ pore-size filter, the number of fluorescent microspheres per eye-piece grid was at most 30 (in samples of LB treatments in Expt 3), usually less than 10. Therefore, flagellates were easily enumerated without any interference by the fluorescent microspheres. At least 200, usually $>300$, cells filter ${ }^{-1}$ of both $U$. americana and HNF were counted. We counted fluorescent microspheres that completely overlapped with flagellate cells in microscope image as ingested particles. For each sample, duplicate filters were used to estimate cell and microsphere densities.
Ingestion rates (IR: food particles cell ${ }^{-1} \mathrm{~h}^{-1}$ ) of flagellates were estimated as:

$$
\begin{aligned}
\mathrm{IR} & =\mathrm{CR} \times(B+F) \\
\mathrm{CR} & =N / F \times 60 / t
\end{aligned}
$$

where CR is the clearance rate for fluorescent microspheres ( $\mathrm{nl}$ cell ${ }^{-1} \mathrm{~h}^{-1}$ ) $B$ and $F$ are the concentrations of bacteria and fluorescent microspheres in the feeding suspension (per nl), $N$ is the number of the fluorescent microspheres ingested by a flagellate cell and $t$ is the feeding time (min). It should be noted that microspheres might land on top of flagellate cells during filtration or adhere during storage of the samples. It was impossible to distinguish the microspheres inside, below and above flagellates by microscopic observation. In initial samples (time $=0$ ), however, it was apparent that microspheres overlapped with flagellate cells were accidentally adhered to the exterior of the cells during the filtration and storage. Therefore, assuming that the frequency of microspheres adhering accidentally to a flagellate cell is the same between initial and final samples, $N$ was estimated as follows:

$$
N=N_{\mathrm{i}}-N_{\mathrm{i}}
$$

where $N_{\mathrm{t}}$ and $N_{\mathrm{i}}$ are the numbers of the microspheres overlapped with a flagellate cell in final and initial samples (time $=0$ ). In Expt 2, since no significant difference was found in $N_{i}$ between the 0 and $2.5 \mu \mathrm{M} P$ treatments, the mean of these was used in the estimation of $\mathrm{CR}$ for all treatments. In all feeding experiments, $N_{\mathrm{i}}$ was less than $10 \%$ of $N_{\mathrm{f}}$ except in LB treatments in Expt 3 , in which it was $28 \%$ of $N_{1}$.

\section{RESULTS}

\section{Expt 1}

During the $48 \mathrm{~h}$ incubation, bacterial density decreased in the treatment without nutrient enrichment $(-P)$ but increased in the treatment with nutrient enrichment $(+P)$. As a result, the final density of bacteria was 1.5 times higher in the $+\mathrm{P}$ relative to $-\mathrm{P}$ treatment (Table 1). In both treatments, HNF density decreased during the incubation but the final density

Table 1. Initial and final densities (cells $\mathrm{ml}^{-1} \pm 3 \mathrm{SE}$ ) of bacteria, HNF and Uroglena americana in Expt $1+\mathrm{P}$ and $-\mathrm{P}$ : treatments with and without nutrient addition

\begin{tabular}{|lccc|}
\hline & Initial & \multicolumn{2}{c|}{ Final } \\
& & $-\mathrm{P}$ & $+\mathrm{P}$ \\
\hline Bacteria $\left(\times 10^{6}\right)$ & 2.84 & $2.02 \pm 0.27$ & $3.33 \pm 0.27$ \\
HNF $\left(\times 10^{3}\right)$ & 4.13 & $0.98 \pm 0.21$ & $2.26 \pm 0.96$ \\
U. americana $\left(\times 10^{3}\right)$ & 0.95 & $3.73 \pm 1.26$ & $3.92 \pm 0.18$ \\
\hline
\end{tabular}


was higher in the $+\mathrm{P}$ than in the $-\mathrm{P}$ treatment. In contrast to HNF, Uroglena americana density showed a 5 -fold increase during the incubation in both the $+P$ and $-\mathrm{P}$ treatments and no significant difference was detected in the final density between the treatments (Table 1).

\section{Expt 2}

Phosphate concentration at the end of the feeding experiment was $0.04 \mu \mathrm{M}$ in treatments without $\mathrm{P}$ enrichment, indicating that the lake water contained at least this concentration of P. However, since the concentration in all of the enriched $\mathrm{P}$ treatments was much higher than that in lake water, the $P$ level in each treatment was essentially an enriched concentration. Among treatments with different $\mathrm{P}$ enrichment, ANOVA showed no significant difference in bacterial density (Fig. 1), probably because of the short incubation time (1.25 h). However, IR of Uroglena americana for food particles (bacteria + microspheres) differed significantly according to the level of $\mathrm{P}$ enrichment. It was 2.5 particles cell ${ }^{-1} \mathrm{~h}^{-1}$ in the treatments without $\mathrm{P}$ enrichment but was reduced dramatically when the concentration was enriched to $0.4 \mu \mathrm{M}$ P. Further increases in $\mathrm{P}$ concentration only slightly lowered the IR beyond this initial response. In contrast to the IR of $U$. americana, no significant difference was detected between the IR of HNF and the P concentration.

To examine the effects of potassium, we enriched lake water with $2.5 \mu \mathrm{M} \mathrm{KCl}$. No significant difference was found, however, in the IR of Uroglena americana and HNF between the treatments with and without $\mathrm{KCl}$ enrichment (Table 2).

\section{Expt 3}

Bacterial density at the end of the feeding experiment was $5.21 \times 10^{6}$ cell ml $^{-1}$ in HB treatments and 2.46 $\times 10^{6}$ cell $\mathrm{ml}^{-1}$ in LB treatments, and was not affected by $\mathrm{P}$ enrichment. This implies that the total density of

Table 2. Ingestion rate (food particles cell ${ }^{-1} \mathrm{~h}^{-1} \pm 3 \mathrm{SE}$ ) of Uroglena americana and HNF in treatments with and without $\mathrm{KCl}$ addition. Number of replicates is shown in parentheses

\begin{tabular}{|lcccccc|}
\hline & \multicolumn{3}{c}{ Treatments } & \multicolumn{3}{c|}{ ANOVA } \\
& Control & $\mathrm{KCl}(2 \mu \mathrm{M})$ & $\mathrm{df}$ & $F$ & $\mathrm{p}$ \\
\hline U. americana & $2.550 \pm 0.180$ & $2.570 \pm 0.080$ & 1,4 & 0.04 & 0.86 \\
HNF & $(3)$ & $(3)$ & & & \\
& $3.450 \pm 0.350$ & $3.350 \pm 0.050$ & 1,4 & 0.69 & 0.45 \\
& $(3)$ & $(3)$ & & & \\
\hline
\end{tabular}
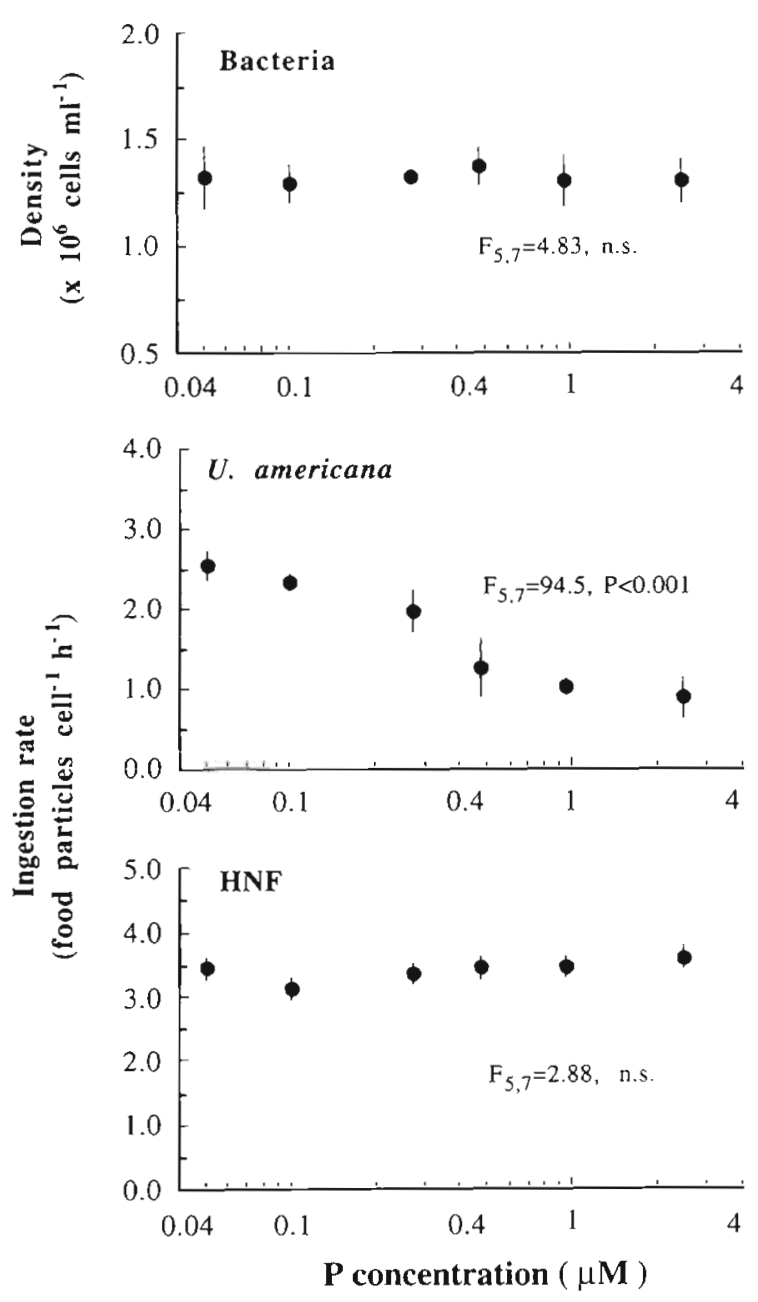

Fig. 1 Density of bacteria and ingestion rate of Uroglena americana and HNF plotted against phosphate concentration at the end of feeding in Expt 2. Vertical bars are 3 SE between replicates. $F$ and significant probability values (ANOVA) for effects of phosphate concentration are indicated. n.s.: probability larger than 0.05

food particles (microspheres + bacteria) for flagellates was $5.54 \times 10^{6}$ particles $\mathrm{ml}^{-1}$ in $\mathrm{HB}$ and $3.31 \times 10^{6}$ particles $\mathrm{ml}^{-1}$ in LB treatments.

Both food particle density and phosphorus enrichment affected the IR of Uroglena americana (Fig. 2). ANOVA revealed no interaction effects of food density and phosphorus enrichment, indicating that IR was affected by these factors independently. At a fixed food density, $U$, americana showed a lower IR in response to $P$ enrichment: IR was decreased by $45 \%$ in HB treatments and $64 \%$ in LB treatments due to P enrichment. In addition, $U$. americana had a higher IR in HB than LB treatments when phosphate concentration was the same. IR of HNF was also affected by food density and was higher in HB than LB treatments. However, it was not affected by $\mathrm{P}$ enrichment. 


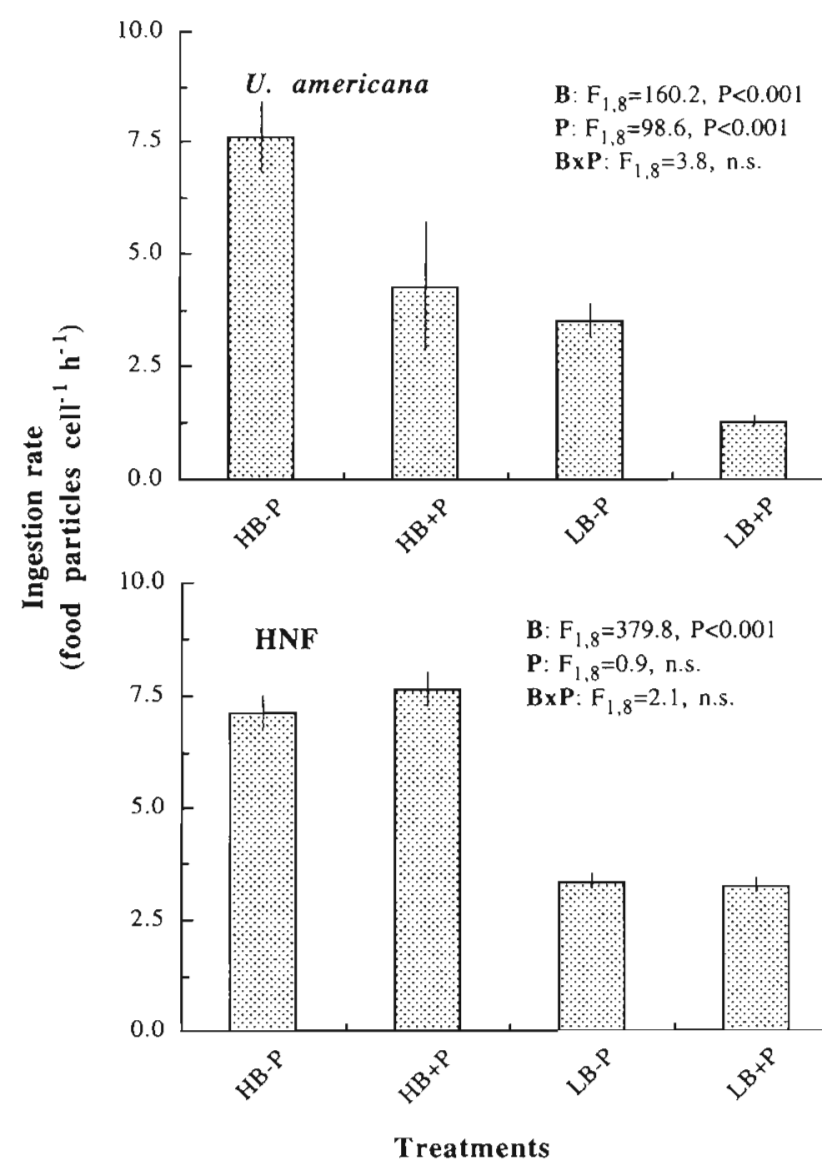

Fig. 2. Effects of food particle density and phosphate concentration on ingestion rate of Uroglena americana and HNF (Expt 3). HB: treatments with high density of bacteria-size particles; LB: treatments with low density of bacteria-size particles; $+P$ : treatments with phosphorus addition $(2 \mu \mathrm{M})$; and $-\mathrm{P}$ : treatments without phosphorus addition. Vertical bars are 3 SE between replicates. $F$ and significant probability values (2-way ANOVA) for food particle density (B), phosphate concentration $(\mathrm{P})$ and their interaction $(\mathrm{B} \times \mathrm{P})$ are indicated. n.s.: probability larger than 0.05

\section{DISCUSSION}

Our study demonstrates that the relative importance of the phagotrophic mode of nutrition in Uroglena americana changes according to ambient $\mathrm{P}$ supply. These results coincide with those obtained by Nygaard \& Tobiesen (1993) who showed that some marine chrysophytes increased phagotrophic grazing when $P$ is limited. The response of the IR of food particles (bacteria + microspheres) that we observed suggests that $U$. americana can gain P from bacteria at low inorganic $\mathrm{P}$ concentrations, and that the strength of the trophic interaction between $U$. americana and bacteria changes according to the nutrient conditions in the ambient water. The IR of $U$. americana and HNF estimated here ( 1 to 8 particles cell ${ }^{-1} \mathrm{~h}^{-1}$ ) falls within the range of rates measured previously with various procedures for several mixotrophic algae and HNF (Sanders et al. 1989, Bennett et al. 1990, Gonzalez et al. 1990, Nygaard \& Tobiesen 1993, Nakano et al. 1998). This implies that IR estimated by our microsphere method is not far from the actual rate for bacteria.

In Expt 3, the IR of Uroglena americana was significantly lower in LB than in HB treatments when phosphate concentration was the same. In addition, compared to Expt 3,U. americana showed a lower IR in Expt 2 when bacterial density was low. These results suggest that the phagotrophic mode of nutrition in $U$. americana depends on bacterial density as well as the ambient P supply. The IR of HNF was also affected by bacterial density, as shown in other studies (e.g. Fenchel 1987). In contrast to the strong effects on $U$. americana, however, no effects of added phosphorus on the IR of HNF were observed. The result is reasonable because HNF have to ingest bacteria to gain energy and carbon. However, if the HNF in our experiments could acquire enough $\mathrm{C}$ but not $\mathrm{P}$ from bacteria relative to their demand and if they could take up $P$ from the water, it would be possible for them to reduce their IR with increasing inorganic $P$ in the water. The lack of response of the IR in HNF to changes in P concentration suggest either that they were $\mathrm{C}$ (or energy)limited or that they cannot take up P from the water.

One potential error source that may decrease the IR of Uroglena americana in P treatments is the effect of potassium. In the feeding experiments, we added $\mathrm{P}$ to lake water as $\mathrm{KH}_{2} \mathrm{PO}_{4}$. It is known that high potassium concentration can depress and inhibit the growth of some chrysophyte species (Lehman 1976, Sandgren 1988). However, no significant difference was detected in the IR of $U$. americana between the treatments with and without $2.5 \mu \mathrm{M} \mathrm{KCl}$. Furthermore, $U$. americana grew well for $48 \mathrm{~h}$ incubation in Expt 1 where $2.5 \mu \mathrm{M}$ $\mathrm{K}_{2} \mathrm{HPO}_{4}$ was added. These results clearly indicate that addition of $\mathrm{K}$ with $\mathrm{P}$ had no effect on $U$. americana. Nakahara (1981) found that, even when potassium concentration is high, $U$. americana can grow well if the $\mathrm{K} /(\mathrm{Ca}+\mathrm{Mg})$ weight ratio in the medium is in the range from 0.01 to 0.5 . In Lake Biwa, dissolved concentrations of potassium, calcium and magnesium were about $0.8,5.6$ and $1.1 \mathrm{mg} \mathrm{l}^{-1}$, respectively, in spring when the feeding experiments were made ( $M$. Maruo pers. comm.). Thus, even if $5 \mu \mathrm{M} \mathrm{K}$ had been added (in the case of Expt 1), the ratio of $\mathrm{K} /(\mathrm{Ca}+\mathrm{Mg}$ ) would still have been much lower than 0.5 .

One may suspect that a decrease in IR of Uroglena americana with an increase in phosphate concentration is a result of changes in nutritional quality of bacteria rather than a direct effect of inorganic P supply. If the quality of bacteria (chemical composition) is improved by $\mathrm{P}$ addition, $U$. americana likely obtain their 
nutritional demand by ingesting fewer bacteria. If this is the case, we would expect the IR of $U$. americana to be more affected by $\mathrm{P}$ enrichment in $\mathrm{HB}$ than in LB treatments in Expt 3, because the density of bacteria (food item possibly improved by $\mathrm{P}$ addition) was higher in the former treatments. However, this was not the case: the decrease in IR due to $P$ enrichment was larger in LB than in HB treatments (Fig. 2). Therefore, the decrease in phagotrophy of $U$. americana at high levels of inorganic $\mathrm{P}$ is unlikely to be attributable to changes in the nutritional quality of bacteria.

Our results show that $0.4 \mu \mathrm{MP}$ is enough to reduce bacterial ingestion by Uroglena americana (Fig. 2). However, $U$. americana did not cease phagotrophy even when inorganic $\mathrm{P}$ supply was high $(2.5 \mu \mathrm{M} \mathrm{P})$. This result supports the idea that a primary reason for phagotrophy in this species is to obtain key phospholipids (Kimura \& Ishida 1989). However, our data suggest that when $P$ is limited in the ambient water, $U$. americana ingest more bacteria than the amount required to assimilate phospholipids. This seems reasonable given the fact that organisms have to acquire $\mathrm{P}$ to synthesize phosphorus-rich molecules such as RNA, which is a major component of cellular P (Elser et al. 1996). Thus, it is advantageous for $U$. americana to use bacteria as a substitutable P source when $\mathrm{P}$ is in limited supply regardless of the need for phospholipids. Ishida et al. (1982) indicated that algal growth was most limited by $\mathrm{P}$ just before $U$. americana developed a dense bloom. The ability of $U$. americana to exploit bacteria as a substitutable P source should allow the species to develop and maintain dense populations compared to phototrophic algae that are unable to access $\mathrm{P}$ bound by bacteria.

In Expt 1, the HNF density decreased during the $48 \mathrm{~h}$ incubation, while Uroglena americana increased in both $+\mathrm{P}$ and $-\mathrm{P}$ treatments. It should be noted that the $<100 \mu \mathrm{m}$ lake water filtrate contained microzooplankton (such as rotifers, ciliates and naupliar stages of copepods) that prey on flagellates. Thus, the decrease in HNF during the incubation might have been due to predation by these microzooplankton. If this is true, the increase in $U$. americana density we observed implies that this alga is less vulnerable to microzooplankton predation. Indeed, $U$. americana form colonies that should be effective in protecting them from predation by microzooplankton. The ability to escape predation may also contribute to the ability of this alga to develop blooms.

Finally, we would like to point out a problem in methods for estimating the grazing rate on bacteria suggested by our data. A common method for measuring grazing loss rate of bacteria is the in situ bottle incubation experiment with dilution technique (Landry \& Hassett 1982). In such experiments, nutrients are sometimes enriched to remove the stimulation effect of nutrient recycling by grazers on bacterial growth rate. However, as demonstrated here, nutrient enrichment may reduce ingestion rate of some mixotrophic algae and result in an underestimate of the grazing on bacteria. Thus, in situations where mixotrophic algae are dominant, caution is needed in interpreting experiments that use nutrient enrichment to estimate the grazing loss rate of bacteria.

Acknowledgements. We thank T. Ueda and. T. Koitabashi for their assistance with the field work. Comments by W. Vincent, $\mathrm{J}$. Elser and an anonymous referee improved the manuscript. The authors are indebted to R. W. Sanders for his invaluable suggestions. This study was financially supported by a Grantin-Aid for Scientific Research (B) 10440234 and Creative Basic Research 09NP1501 from the Ministry of Education, Science, Sports and Culture of Japan.

\section{LITERATURE CITED}

Aaronson S, Baker H (1959) A comparative biochemical study of two species of Ochromonas. J Protozool 6:282-284

Bennett SJ, Sanders RW, Porter KG (1990) Heterotrophic, autotrophic, and mixotrophic nanoflagellates: seasonal abundances and bacterivory in a eutrophic lake. Limnol Oceanogr 35:1821-1832

Bird BF, Kalff $J$ (1986) Bacterial grazing by planktonic lake algae. Science 231:493-495

Caron DA, Porter KG, Sanders RW (1990) Carbon, nitrogen, and phosphorus budgets for the mixotrophic phytoflagellate Poterioochromonas malhamensis (Chrysophyceae) during bacterial ingestion. Limnol Oceanogr 35:433-443

Caron DA, Sanders RW, Lim EL, Marrase C, Amaral LA, Whitney S, Aoki RB, Porter KG (1993) Light-dependent phagotrophy in the freshwater mixotrophic chrysophyte Dinobryon cylindricum. Microb Ecol 25:93-111

Currie DJ, Kalff J (1984) The relative importance of bacterio. plankton versus phytoplankton in phosphorus uptake in freshwater. Limnol Oceanogr 29:311-312

Elser JJ, Dobberfuhl D, MacKay NA, Schampel JH (1996) Organism size, life history, and N:P stoichiometry: towards a unified view of cellular and ecosystem processes. Bioscience 46:674-684

Fenchel T (1987) Ecology of protozoa. Science Tech, Madison

Gonzalez JM, Sherr EB, Sherr BF (1990) Size-selective grazing on bacteria by natural assemblages of estuarine flagellates and ciliates. Appl Environ Microbiol 56:583-589

Hobbie JE, Daley RD, Jasper S (1977) Use of Nuclepore filters for counting bacteria by fluorescence microscopy. Appl Environ Microbiol 33:1225-1228

Ishida Y, Kimura B, Nakahara H, Kadota H (1982) Analysis of major nutrient effecting Uroglena americana bloom in the northern Lake Biwa, by use of algal bioassay. Bull Jpn Soc Sci Fish 48:1281-1287

Kimura B, Ishida Y (1986a) Effect of naturally collected bacteria on growth of Uroglena americana, a freshwater red tide Chrysophyceae. Bull Jpn Soc Sci Fish 52:691-696

Kimura B, Ishida Y (1986b) Possible phagotrophic feeding of bacteria in a freshwater red tide Chrysophyceae, Uroglena americana. Bull Jpn Soc Sci Fish 52:697-701

Kimura B, Ishida Y (1989) Phospholipid as a growth factor of Uroglena americana, a red tide Chrysophyceae in Lake 
Biwa. Nippon Suisan Gakkaishi 55:799-804

Landry MR, Hassett RP (1982) Estimating the grazing impact of marine micro-zooplankton. Mar Biol 67:283-288

Lehman JT (1976) Ecological and nutritional studies on Dinobryon Ehrenb.: seasonal periodicity and the phosphate toxicity problem. Limnol Oceanogr 21:646-658

Nagata T (1986) Carbon and nitrogen content of natural planktonic bacteria. Appl Environ Microbiol 52:28-32

Nagata T (1988) The microflagellate-picoplankton food linkage in the water column of Lake Biwa. Limnol Oceanogr 33:504-517

Nakahara $H$ (1981) Life history of Uroglena americana. In Kadota $\mathrm{H}$ (ed) Research report on phytoplankton bloom in Lake Biwa. Kyoto University, Kyoto, p 137-144 (in Japanese)

Nakano S, Koitabashi T, Ueda T (1998) Seasonal changes in abundance of heterotrophic nanoflagellates and their consumption of bacteria in Lake Biwa with special reference to trophic interaction with Daphnia galeata. Arch Hydrobiol 142:21-34

Nygaard K, Tobiesen A (1993) Bacterivory in algae: a survival strategy during nutrient limitation. Limnol Oceanogr 38 $273-279$

Raven JA (1997) Phagotrophy in phototrophs. Limnol Oceanogr 42:198-205

Rothhaupt KO (1996) Utilization of substitutable carbon and phosphorus sources by the mixotrophic chrysophyte Ochromonas sp. Ecology 77:706-715

Rothhaupt KO, Güde H (1992) The influence of spatial and temporal concentration gradients on phosphate partition-

Editorial responsibility: Robert Sanders, Philadelphia, Pennsylvania, USA ing between different size fractions of plankton: further evidence and possible causes. Limnol Oceanogr 37: $739-749$

Sanders RW, Porter KG (1988) Phagotrophic phytoflagellates. In: Marshall KC (ed) Advances in microbial ecology, Vol 10. Plenum, New York, p 167-192

Sanders RW, Porter KG, Bennett SJ, DeBiase AE (1989) Seasonal patterns of bacterivory by flagellates, ciliates, rotifers, and cladocerans in a freshwater planktonic community. Limnol Oceanogr 34:673-687

Sandgren CD (1988) The ecology of chrysophyte flagellates: their growth and perennation strategies as freshwater phytoplankton. In: Sandgren CD (ed) Growth and reproductive strategies of freshwater phytoplankton. Cambridge University Press, Cambridge, p 9-104

Sherr EB, Sherr BF (1983) Double-staining epifluorescence technique to assess frequency of dividing cells and bacterivory in natural populations of heterotrophic microprotozoa. Appl Environ Microbiol 46:1388-1393

Tezuka Y (1985) C:N:P ratios of seston in Lake Biwa as indicators of nutrient deficiency in phytoplankton and decomposition process of hypolimnetic particulate matter. Jpn J Limnol 46:239-246

Thingstad TF, Havskum H, Garde K, Riemann B (1996) On the strategy of 'eating your competitor': a mathematical analysis of algal mixotrophy. Ecology 77:2108-2118

Yoshida Y, Mitamura O, Tanaka N, Kadota H (1983) Studies on a freshwater red tide in Lake Biwa - I. Changes in the distribution of phytoplankton and nutrients. Jpn J Limnol 44:21-27

Submitted: September 29, 1998; Accepted: December 8, 1998 Proofs received from author(s): July 6, 1999 